Grażyna STAchówna

\title{
Żelary Květy Legátovej w reżyserii Ondřeja Trojana - beskidzki melodramat
}

Do wszystkiego potrzebny jest talent. Do szczęścia też.

Květa Legátová ${ }^{1}$

Opublikowanie w 2001 r. tomu poetyckich opowiadań Květy Legátovej Żelary (Želary) obrosło w Czechach legendą. Był to debiut literacki 82-letniej autorki, który niespodziewanie zyskał uznanie krytyki i popularność wśród licznych czytelników. Nakład szybko przekroczył 60 tysięcy egzemplarzy. W rankingu gazety "Lidové noviny” Żelary zostały uznane za najlepszą książkę roku, a Legátová uzyskała za nie nagrodę państwową (2002). Sędziwy wiek autorki, tak późny debiut i wielki sukces budziły zrozumiałe zainteresowanie. Po niejakim czasie okazało się, że Květa Legátová to pseudonim Věry Hofmanovej, pisarki, która publikowała swe prace, bez większego sukcesu, od 1957 r. Tylko data jej urodzin, 3 stycznia 1919 r., okazała się prawdziwa.

Věra Hofmanová przyszła na świat we wsi Podolí koło Brna w rodzinie nauczycielskiej. Uzyskała bardzo solidne wykształcenie uniwersyteckie, jest absolwentką bohemistyki, germanistyki, fizyki i matematyki. Całe życie pracowała w wiejskich szkołach w południowo-wschodnich Morawach, dokąd wysyłały ją komunistyczne władze ${ }^{2}$. Tworzyć zaczęła wcześnie i w oryginalny sposób - dla radia. W 1940 r. ojciec Věry przyniósł do rozgłośni napisane przez nią skecze, ale podobno redaktorzy nie uwierzyli w autorstwo dwudziestolatki i kazali mu przyprowadzić córkę. W $1948 \mathrm{r}$. nadano pierwsze słuchowisko Hofmanovej Olga Jeglavičová, a potem jeszcze

1 Květa Legátová, Hanulka Jozy, tłum. Dorota Dobrew, Wyd. Dwie Siostry, Warszawa 2008, s. 124.

2 Izabela Janicka, W świecie piękna i szaleństwa, „Czas Kultury” 2007, nr 1-2, s. 189-191. 
dwadzieścia innych. W latach 1972-1991 radio czechosłowackie nie emitowało jej sztuk. Wiele lat później Hofmanová opublikowała je w dwu tomach, Pro každého nebe (Dla każdego niebo, 2003) i Posedlá a jiné hry (Opętana $i$ inne sztuki, 2004), za które uzyskała nagrodę Prix Bohemia ${ }^{3}$.

W 1957 r. ukazał się tom opowiadań Hofmanovej Postavičky (Małe postaci), opublikowany pod pseudonimem Věra Podhorná, przedstawiający literackie miniatury dzieci - został chłodno przyjęty przez krytykę. W 1961 r. pod tym samym pseudonimem wydała jeszcze powieść Korda Dabrová. Już po sukcesie Żelar opublikowała dwa zbiory, opowiadania kryminalne Nic není tak prosté (Nic nie jest takie proste, 2006) i teksty dramatyczne Mušle a jiné odposlechy (Muszle i inne stuchowiska, 2007).

Żelary powstawały długo. Hofmanová-Legátová tak o tym mówiła: „Żelary napisałam właściwie już trzydzieści lat temu, a teraz tylko połączyłam opowiadania w cykl, który znajduje się w tej książce ${ }^{\prime \prime 4}$. Pytana o to, czy sukces nie przyszedł zbyt późno, odpowiada: „Ani trochę. Przecież mógł się nie zdarzyć w ogóle, wszystko mogło na zawsze zostać w szufladzie" ${ }^{\prime \prime}$.

Pierwowzorem literackich Żelar jest wieś Starý Hrozenkov, leżąca na granicy Moraw i Słowacji, gdzie Hofmanová była nauczycielką. Tom zawiera osiem opowiadań przedstawiających splecione ze sobą losy dwu pokoleń mieszkańców Żelar. Akcja rozgrywa się w czasie tzw. Pierwszej Republiki Czechosłowackiej (1918-1938). Występują w nich ci sami bohaterowie, w jednych opowiadaniach pojawiają się jako postaci główne, w innych epizodyczne, prezentowani są w różnym okresie ich życia i w odmienny sposób, o czym decydują opisywane fakty i ujawniane tajemnice. Pierwowzorami byli prawdziwi mieszkańcy beskidzkich wsi, jakich autorka poznała w czasie swej pracy nauczycielskiej.

Hofmanová-Legátová przedstawia swych bohaterów z wielką życzliwością, tworząc przenikliwe portrety mężczyzn, kobiet i dzieci, ludzi o barwnych osobowościach i skomplikowanych psychikach, ożywianych gwałtownymi namiętnościami i skrywających wiele tajemnic. Kolejne opowiadania zmieniają pierwotną ocenę protagonistów: dobrzy ujawniają brzydkie skazy, a źli okazują się głęboko nieszczęśliwi lub złamani przez osobiste tragedie. Autorka przy pomina starą prawdę, by nie wierzyć pierwszym wrażeniom, ponieważ nic nie jest takie, jak się pozornie wydaje. Oto modlitwa żelarskiego księdza: Jakże jesteśmy nieświadomi, Panie. Pragniemy

\footnotetext{
Leszek Engelking, Opowiadania wyjęte z szuflady, „Nowe Książki” 2006, nr 10, s. 20-21.

4 Tamże, s. 20.

5 Za: Leszek Engelking, Talent do szczęścia, „Nowe Książki” 2008, nr 7, s. 66.
} 
czynić dobro, a dopuszczamy się zbrodni ${ }^{6}$. Dobre uczynki mogą mieć tragiczne skutki, a przestępstwa bywają popełniane ze szlachetnych pobudek. Nawet miłość często prowadzi do nieszczęścia, niczego nie usprawiedliwia ani nie rozgrzesza. Świat górskiej wioski jest surowy i prymitywny, podporządkowany żywiołowi otaczającej przyrody, hermetycznie zamknięty, ograniczony przesądami i uprzedzeniami. Jej mieszkańcy często postępują źle i okrutnie, ale zdobywają się też na heroiczne gesty i z uporem walczą o swe szczęście. Do opisu żelarskiej rzeczywistości Hofmanová-Legátová zastosowała język potoczny, często dosadny, niestroniący jednak od poetyckiej sublimacji i wzniosłości ${ }^{7}$. Oto opinia polskiego krytyka: ,[...] przemyślana i wyrafinowana kompozycja, znakomity, choć niewątpliwie tradycyjny, nieomal staroświecki warsztat, własny styl i szczególne wymieszanie detali ujętych wręcz naturalistycznie $\mathrm{z}$ tonem poetyckim, miejscami lirycznym"s.

Opowiadanie Hanulka Jozy (Jozova Hanule, 2002) zostało napisane przez Hofmanovą-Legátovą na konkurs na nowelę filmową. Natknął się na nie scenarzysta Petr Jarchovský. Wraz z producentem Ondřejem Trojanem odnaleźli sędziwą autorkę w Brnie, gdzie mieszkała ze swymi kotami. Zgodziła się na publikację opowiadania i jego adaptację?. W 2003 r. Trojan nakręcił na podstawie Hanulki Jozy film fabularny Żelary, który zdobył nominację do nagrody Oscara w kategorii najlepszy film obcojęzyczny (2004).

Hofmanová-Legátová z dystansem odniosła się do kinowej adaptacji Hanulki Jozy. Powiedziała: „Film to scenariusz, reżyseria, aktorzy. Oni go stworzyli. Powstał wprawdzie na podstawie mojego opowiadania, ale nie mam prawa wypowiadać się o nim inaczej niż z pozycji widza. Mnie dał to, że także książka jest bardziej znana"10.

W polskich kinach pokazano Żelary w 2007 r., cztery lata po premierze; film przeminął niemal bez echa. Pojawiły się tylko cztery recenzje, ciepłe, ale zdawkowe; branżowe „Kino” w ogóle go nie odnotowało. Anonimowy autor napisał w ,Tygodniku Powszechnym”: „Kino czeskie w nietypowej odsłonie: rozlewna epika, w tle II wojna światowa, nieproste uczucia i proste życie gdzieś na obrzeżach cywilizacji”"111. Lech Kurpiewski

6 Květa Legátová, Żelary, tłum. Dorota Dobrew, Wyd. Dwie Siostry, Warszawa 2006, s. 260.

7 Zofia Tarajło-Lipowska, Historia literatury czeskiej. Zarys, Zakład Narodowy im. Ossolińskich - Wydawnictwo, Wrocław 2010, s. 440.

8 Leszek Engelking, Opowiadania wyjęte z szuflady, s. 20-21.

9 Izabela Janicka, dz. cyt.

10 Za: Leszek Engelking, Talent do szczęścia...

11 Anonimowa notka, Żelary, „,Tygodnik Powszechny” 2008, nr 34, s. 38. 
$\mathrm{w}$ „Newsweeku": ,[...] rasowa epopeja - demony wojny, ludzkie cierpienia i olśniewająca przyroda"12. Łukasz Maciejewski w „Filmie”: „Ondřej Trojan wygrywa emocjonalną amplitudę spokojnie i z wyrozumiałością"13. Opinie internautów na stronie Filmweb były niemal tylko entuzjastyczne: „Film idealny w każdym calu”, „W mojej opinii to arcydzieło”, „Porównajcie Katyń i Żelary, nasi czescy sąsiedzi wygrywają ${ }^{\prime 14}$.

$$
* \quad * \quad *
$$

Film Ondřeja Trojana Żelary, nakręcony według scenariusza Petra Jarchovskiego, stanowi "szczególny przypadek lektury” - jak to określa Robert Escarpit ${ }^{15}$ - opowiadania Květy Legátovej Hanulka Jozy, wzbogaconego kilkoma wątkami pochodzącymi z tomu Żelary, z którego też przejęto tytuł dla kinowego dzieła. Są to wydarzenia związane z postaciami dzieci, Helenki Bojarovej i Vratislava Lipki; Michała Kutiny, ojczyma Vratislava - pijaka dręczącego chłopca; księdza i nauczyciela reprezentujących dwie racje - tolerancji dla ludzkich występków i surowości wobec nich; starego Gorčika, który wiąże się z młodziutką synową poniewieraną przez jego syna. Wątki te dopełniają akcję filmu, ale nie przesłaniają jego głównego tematu, jakim jest opowieść o wymuszonym małżeństwie miastowej dziewczyny i wiejskiego prostaka. Scenarzysta wymyślił także dwie sceny dodatkowe - próbę gwałtu na Hanulce, której dopuszcza się Michał oraz sekwencję finałową, przyjazd Hanulki po latach do Żelar.

W kinowym procesie adaptacyjnym film Trojana, jak zawsze zresztą, dopuszcza się zdrady literackiego oryginału Legátovej, choć z pewnością - jak by powiedział Robert Escarpit - „zdrady twórczej”"16. Jarchovský i Trojan znaleźli bowiem właściwą „dyspozycję wykonawczą”, która stała się - wedle ustaleń Jerzego Ziomka - właściwym „sposobem wygłoszenia" Hanulki Jozy w innym medium niż literatura. Jego zdaniem w każdym utworze literackim, nawet tym napisanym przed powstaniem nowych mediów, tkwi bowiem "dyspozycja wykonawcza” pozwalająca, dzięki twórczej wyobraźni adaptatorów, dostosować go do nowego środka

12 Lech Kurpiewski, Miłość i demony wojny, „Newsweek. Polska” 2007, nr 33, s. 101.

13 Łukasz Maciejewski, Żelary, „Film” 2007, nr 8, s. 79.

14 Por.: www.filmweb.pl/Zelary/discussion (dostęp: sierpień 2012).

15 Robert Escarpit, Literatura a społeczeństwo, tłum. Janusz Lalewicz, [w:] Wspótczesna teoria badań literackich za granica. Antologia, red. Henryk Markiewicz, Wyd. Literackie, Kraków 1976, t. 3, s. $167-168$.

16 Tamże. 
przekazu, kinowego, teatralnego, telewizyjnego, radiowego, estradowego, "growego" (przeznaczonego dla gier komputerowych) itd. ${ }^{17}$ Spróbujmy zatem określić zasady filmowej „dyspozycji wykonawczej” odkrytej w prozie Legátovej przez Jarchovskiego i Trojana.

Konstrukcja fabularna opowiadania Hanulka Jozy i powstałego na jego podstawie filmu Żelary powiela jeden z najbardziej tradycyjnych schematów melodramatycznych - dwoje krańcowo różnych i obcych sobie ludzi zmuszonych jest zawrzeć zaaranżowany związek małżeński, wspólne przebywanie ze sobą odkrywa im niezwykłe zalety partnera, rodzi się między nimi więź romantyczna, pragmatyczny układ zamienia się w prawdziwą miłość. Wykorzystano go w kinie już wiele razy, m.in. w Wichrze (1928), Markizie Angelice (1964), Sidłach (1966), Komedii z pomyłek (1967), Narzeczonej Zandy'ego (1974), Lady Jane (1986), Do zakochania jeden krok (2008). Jeśli kolejny raz ta stara romansowa struktura ma zaciekawić i wzruszyć widzów, a do tego okazać swą nieprzemijającą urodę, musi spełnić kilka podstawowych warunków: niebanalni bohaterowie, przekonujący powód, dla którego zmuszeni są wziąć ślub, wzruszające pokazanie stopniowego rodzenia się uczucia, spełnienie emocjonalne i erotyczne, poruszający finał. W filmowej Hanulce Jozy klasyczna, melodramatyczna formuła została wykorzystana zręcznie i z wyczuciem.

Główną bohaterką filmu Żelary Ondřeja Trojana jest młoda, około dwudziestotrzyletnia, złotowłosa, nadzwyczaj urodziwa Eliška (Aňa Geislerová), pielęgniarka z Brna. Pracuje w szpitalu, ma romans z przystojnym chirurgiem Richardem (Ivan Trojan), należy do tajnej organizacji walczącej z Niemcami okupującymi Czechosłowację - trwa bowiem druga wojna światowa, akcja filmu zaczyna się w maju $1943 \mathrm{r}$.

W opowiadaniu Hanulka Jozy Květy Legátovej Eliška jest kobietą bardziej dojrzałą, około trzydziestoletnią, ma dyplom lekarza. To ona pełni funkcję narratorki i w pierwszej osobie, subiektywnie, relacjonuje swą historię czytelnikom. Jej oczami oglądamy beskidzką wioskę, mieszkańców, wszystkie dziejące się wydarzenia i przede wszystkim Jozę (zdrobnienie od Josef) Jandę, za którego wychodzi za mąż.

Inicjalna sekwencja filmowych Żelar rozpoczyna się efektowną sceną miłosną Eliški i Richarda ${ }^{18}$, widz kinowy odnosi wrażenie, że to oni będą głównymi bohaterami filmu. Richard zostaje wezwany do szpitala, do

17 Jerzy Ziomek, Powinowactwa literatury. Studia i szkice, PWN, Warszawa 1980, s. 110-125.

18 Podobno Ivan Trojan, sławny aktor i młodszy brat reżysera, zgodził się odtwarzać epizodyczną rolę Richarda za zagranie sceny miłosnej z Aňą Geislerovą. Patrz: anonimowa notatka, Film z cyklu „Wiesz, co dobre”, „Przekrój” 2010, nr 25, s. 51. 
poranionego drwala, któremu ma zrobić operację. Zabiera ze sobą Eliškę, jadą samochodem, po drodze legitymują ich niemieccy żandarmi. Richard przeprowadza operację, ratuje pacjentowi życie. Choremu Jozie (György Cserhalmi ${ }^{19}$ ) potrzebna jest krew, Eliška daje mu swoją. Leży obok obcego człowieka, krew przepływa z jej żył do jego i w patruje się uważnie w twarz mężczyzny. Widz spodziewa się, że Joza odpowie jej równie uważnym spojrzeniem, nawiązującym między nimi emocjonalny kontakt. Ale drwal jest nieprzytomny, a jego twarz zasłania maska tlenowa ułatwiająca mu oddychanie. Wymiana spojrzeń nie następuje. Joza pozostaje dla Eliški i dla widza - anonimowy.

W melodramatach pierwsze spojrzenie wymienione przez dwoje bohaterów, zwykle przedłużone i nabrzmiałe emocjonalnym znaczeniem, ma ogromną wagę dramaturgiczną, ponieważ ujawnia przyszłych kochanków i informuje o zrodzeniu się tzw. miłości od pierwszego wejrzenia. Widzowie kinowi, znający tę regułę, bezbłędnie rozpoznają wstęp do takiej wymiany spojrzeń w sposobie, w jaki Eliška spogląda na Jozę. Brak odpowiedzi z jego strony znacząco odświeża starą i zbanalizowaną konwencję: drwal nie nabiera znaczenia jako jej potencjalny partner, piękna Eliška nadal jest zakochana w Richardzie, a domyślność widza zostaje wystawiona na próbę.

Eliška bierze udział w akcji dywersyjnej, ma dostarczyć kopertę zawierającą tajne informacje pod wskazany adres. Ale mieszkanie odbiorców zostało odkryte przez Niemców, założyli w nim „kocioł”, Elišce cudem udaje się uniknąć aresztowania, musi natychmiast zniknąć z Brna. Richard już uciekł, nie oglądając się na kochankę. Slávek, dowódca organizacji, postanawia, że Eliška wyjedzie z miasta z wyleczonym już Jozą do Żelar, wsi leżącej w Beskidach, gdzie się ukryje. Dostaje nowe dokumenty, teraz będzie się nazywać Hana Hofmanová - w opowiadaniu Novaková. Spotykają się z Jozą na dworcu i jadą razem pociągiem do miejscowości Šadová Hut'. Podczas drogi oboje są bardzo zakłopotani, nie mają sobie bowiem nic do powiedzenia. Dziewczyna przygląda się z odrazą wielkim rękom drwala. Joza umieszcza ją w hoteliku Irčy Mareniny. Eliška obserwuje, jak na ulicy dzieci dokuczają małej dziewczynce, Helence. Na pytanie, dlaczego to robią, Irča odpowiada: Mieszka w Żelarach. O świcie Eliška, przerażona obcością otoczenia, ucieka chyłkiem na dworzec, ale odnajduje ją tam doktor Beniček i przekazuje jej wieść o aresztowaniu i śmierci

19 Wybitny węgierski aktor (ur. 1948), grał w filmach m.in. Miklósa Jancsó, Istvána Szabó, Béli Tarra. 
Slávka. Jeśli nie wytrzymał on tortur podczas przesłuchania i ujawnił towarzyszy z organizacji, życie Eliški także jest zagrożone. Doktor radzi jej, by wyszła za mąż za Jozę i w ten sposób zatarła za sobą wszelkie ślady.

W opowiadaniu Legátovej Joza już w szpitalu w Brnie nie krył swej radośc $i^{20}$ na widok leczącej go lekarki Eliški, co budziło rozbawienie personelu. Ten wsiok jest w tobie zakochany ${ }^{21}$ - powiedział jeden z jej kolegów. Potem Slávek, organizując jej ucieczkę z miasta, mówi: Ten kmiotek spadt ci z nieba. Nie musisz się go bać. On cię nie opuści, nawet gdyby miał to przypłacić $\dot{z} y$ ciem $^{22}$. Gdy zapada decyzja o ślubie, Hana pyta Jozę: Czy pan mógłby się ze mna ożenić? [...]. Było jasne, że takiej ewentualności w ogóle nie brał pod uwage [...]. Odpowiedział spokojnie i bez wahania [...]. Tak. [...] Wygladał jak człowiek, który na jawie i w pełni świadomości nie może uwolnić się od snu ${ }^{23}$. W filmie Trojana Joza nie okazuje Elišce specjalnej sympatii w szpitalu, a potem nikt go nie pyta, czy chce się z nią ożenić. Jego zgoda została załatwiona poza kadrem, drwal nie ma okazji do jawnego wyrażenia swej woli - szkoda, bo to zubaża jego postać. Widz nie wie, dlaczego zaakceptował małżeństwo może z miłości do Eliški, a może go namówiono lub przekupiono?

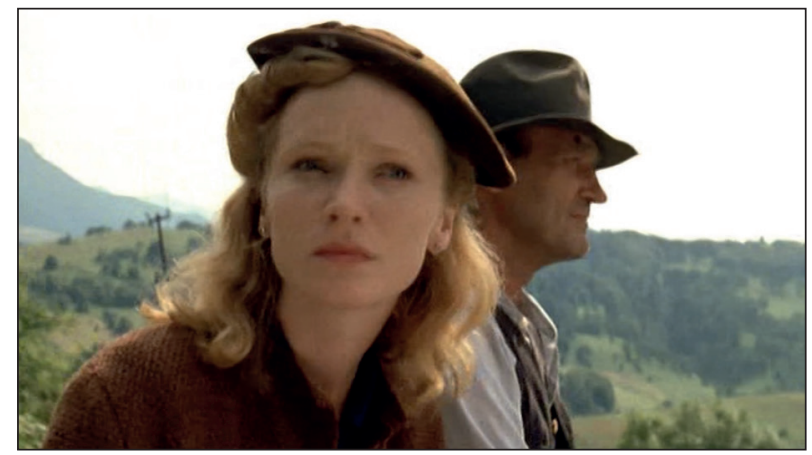

Fot. 13. Żelary (2003, reż. Ondřej Trojan)

Joza wiezie Eliškę do swojej chaty

Joza wiezie Eliškę furmanką do Żelar, do opuszczonej chaty stojącej na stoku wzgórza, z pięknym widokiem na Beskidy. Miejska dziewczyna nie dostrzega jednak urody tego miejsca - widzi tylko prymitywna, brudną chałupę z klepiskiem, nie rozumie, dlaczego musi wziąć ślub w ludowym

20 Květa Legátová, Hanulka Jozy, s. 13.

21 Tamże, s. 16.

22 Tamże, s. 21.

23 Tamże, s. 33. 
stroju i zyskać tym akceptację mieszkańców Żelar. Nie zauważa też, jak zmienia się Joza - w bliskim mu otoczeniu staje się pewny siebie i przedsiębiorczy, sprawnie załatwia różne sprawy i chroni ją nie tylko przed Niemcami, ale także przed zaczepkami innych mężczyzn. W Żelarach to bardzo ważne, stając się żoną Jozy - Hanulką Jozy - Eliška zyskuje nietykalność, broni ją bowiem siła wielkich mężowskich pięści. Już podczas wesela Joza bije pijaka, który ją obraził. Wszyscy widzieli, że jestem naznaczona znamieniem swojego pana ${ }^{24}-\mathrm{z}$ pogardą komentuje to Eliška w opowiadaniu Legátovej.

Przed ślubem ksiądz, wprowadzony przez Jozę w sytuację, zadaje narzeczonym trzy ważne pytania: czy zawierają małżeństwo dobrowolnie? czy nikt ich nie zmusza do ślubu? czy chca mieć potomstwo? Joza odpowiada na nie afirmatywnie, szczerze i z przekonaniem, Eliška kłamie: nie zawiera przecież małżeństwa z własnej woli, jest zmuszona do poślubienia Jozy, nie zamierza mieć z nim dzieci. W ten sposób podważa prawomocność zawieranego sakramentu.

W opowiadaniu Legátovej Eliška patrzy na Jozę z pogardą i lękiem. Myśli o nim: prostak z dalekich gór (s. 13), pótanalfabeta i prymityw (s. 24), tapska Jozy [...] będę wydana na ich pastwę (s. 26), na pewno pije, karczma i koledzy (s. 27), kretyn (s. 34), żelarski głupek (s. 39), odczuwałam niemożliwy do opanowania wstręt (s. 52). Tylko jedna cecha Jozy podoba się jej od początku, odkryła ją jeszcze w szpitalu w Brnie, gdy go leczyła: ma niezwykły dar, umie opowiadać (s. 13). Eliška nie opisuje wyglądu Jozy, ale sugeruje, że jest bardzo nieurodziwy. Nieludzka, wykrzywiona maska (s. 13) - to stan jego twarzy po wypadku, trudno jednak przypuszczać, aby tak poważne zranienie dodało mu potem urody.

W filmie Trojana niczego nie wiadomo o przeszłości Jozy, podobnie jak w opowiadaniu Legátovej Hanulka Jozy. Natomiast w tomie Żelary została ona opisana, mimo że Joza nie jest tam bohaterem pierwszoplanowym. To nieślubny syn Mety Jandovej, która wynajmowała się do pracy w różnych gospodarstwach. Wiejskie dzieci traktowały go z pogardą i okrucieństwem: zawsze był tym, kto je wozit na grzbiecie, kogo poganiały, z kogo się wyśmiewaty. [...] Przetracili mu kamieniem nos. Kto to zrobit, nie wiadomo. Rzucali wszyscy. [...] Ale Joza nie kwilit, nie ronit łez ani się nie skarży ${ }^{25}$. Nazywano go Krzywonos albo Żelazna Łapa, bo był obdarzony wielką siłą. Matka, którą bardzo kochał, napominała go, by tylko nikogo nie ukrzywdzit (s. 76). Po jej śmierci, gdy miał dwanaście lat, ostatni gospodarz, u którego pracowała,

24 Tamże, s. 39. Dalsze cytaty pochodzą także z tego wydania.

25 Květa Legátová, Żelary, s. 278. Dalsze cytaty pochodzą także z tego wydania. 
sprzedał go kowalowi na czeladnika (s. 279), przestał wtedy chodzić do szkoły, ale umiał już czytać i pisać. Pracował bardzo ciężko za leniwego i wiecznie pijanego kowala, w dalszym ciągu lekceważony i źle opłacany. Przywykł do tego, że krzywdy i poniżenia to jego los (s. 77). Był niewiarygodnie dobry i dlatego wszyscy mieli go za głupca (s. 74). To on opiekował się Madlenką-Kuternogą, przeciął obrożę wrośniętą w szyję psa Azora i zaprzyjaźnił się z małą Helenką Bojarovą.

W filmie Trojana Eliška olśniewa urodą, seksapilem i miejskim sznytem, Joza wygląda zaś na typowego wiejskiego prostaka, to mężczyzna w średnim wielu, zaniedbany, nieśmiały i małomówny. Gdy czeka na Eliškę na dworcu w Brnie, wygląda nader komicznie w płaszczu i kapeluszu pożyczonym mu przez Slávka. Ale u siebie, w Żelarach, odzyskuje naturalną swobodę i zaczyna ujawniać ujmujący wdzięk. Nadal niewiele mówi, nie umie niestety opowiadać, ale za to potrafi komunikować się językiem ciała: czułe gesty, tkliwe spojrzenia, ciepłe uśmiechy. Jest miłym, dobrym człowiekiem o niewinnym, chłopięcym usposobieniu.

Eliška i Joza zamieszkują razem w prymitywnej chacie. Przed ślubem dziewczyna barykaduje drzwi komory wielkim kufrem i czuwa z nożyczkami w ręce, gotowa do obrony. Joza śpi w innej izbie na ławie. W noc poślubną Eliška płacze w pościeli, zjawia się Joza, pytając nieśmiało, czy może się przy niej położyć, bo ława jest twarda. Po czym nieoczekiwanie wyznaje: Zdradzałem cię wcześniej... z Irča i błogo zasypia. Zdumiona Eliška nie odwzajemnia mu się podobnym zwierzeniem o romansie łączącym ją z Richardem.

Zgodnie z melodramatyczną formułą organizującą narrację filmu Trojana następuje teraz powolne oswajanie się Eliški/Hany z nowymi warunkami życia i z Jozą. On pracuje w tartaku, ona próbuje być gospodynią. Zaczyna gotować, bardzo źle, co Jozę tylko bawi, bo nawet pies Azor nie chce jeść jej potraw. Żelarski głupek przybija drewnianą podłogę na klepisko, z Šadovej Huti przywozi żonie książki do czytania, nie gniewa się z powodu stłuczonej przez nią lampy naftowej, zawozi ją na grób swej matki, wreszcie kąpie się - co wyraźnie dodaje mu młodości i urody i w wielkim łóżku czule skłania ją do miłości. Eliška staje się Hanulką, prawdziwą Hanulką Jozy.

W opowiadaniu Legátovej można z wybranych krótkich cytatów odtworzyć ten stopniowy proces oswajania, któremu podlega Eliška: Joza zjadał wszystko bez mrugnięcia okiem (s. 57), na razie nie próbował mi rozkazywać (s. 57), umiat anielsko się śmiać (s. 60), całowat mnie w sposób niewiarygodny. Przyciskał usta miękko do mojej twarzy. Wkładał w te swoje dotknięcia 
tyle uczucia, jakby miał do spetnienia jakąś misję (s. 53), niesamowicie nieśmiały. Wyrafinowana sztuka miłości zmysłowej była mu obca (s. 54), Przytuliłam się do swojego męża, bo grzał. Odwrócił się na bok, a jego wolne ramię opadło na mnie jak skrzydło anioła (s. 54).

Zgodnie z przyjętymi zasadami melodramatycznej formuły narracyjnej Hanulka zakochuje się w Jozie. W opowiadaniu tak to relacjonuje: Cud, który się zdarzyt, powstał nagle i dosłownie z niczego (s. 60), W jakiejś kosmicznej ruletce właśnie rozbiłam bank (s. 64), Joza był delikatny w najprostszy z możliwych sposobów (s. 70), Zaczęłam uzależniać się od jego czułości jak od narkotyku (s. 70), Bez Jozy byłabym tworem niepetnym (s. 95), Wystarczało nam, że jesteśmy razem (s. 115), Joza nie wzbudzał żadnych romantycznych wyobrażeń. On je spetniał. Był zaskakujaco przystępna iluzja (s. 118), Jesteś piękny, Jozo (s. 119).

W filmie ten proces zostaje rozpisany na kilka zdarzeń. Jesienią $1943 \mathrm{r}$. Hanulka gubi się w lesie, gdzie zaskakuje ją burza. Odnajduje ją pies Azor, a Joza na rękach przynosi ją do domu i potem czule opiekuje się nią w czasie choroby. Zimą 1944 r. Hanulka zostaje napadnięta w tartaku, gdzie przyszła się wykąpać, przez Michała Kutinę. Joza nie tylko ją broni, ale także przykładnie karze gwałciciela, bijąc go i łamiąc mu ramię. Wkrótce potem Hanulka i Joza próbują zawieźć na sankach podczas śnieżnej zawiei do szpitala w dolinie żonę Michała, która poroniła, ale kobieta umiera po drodze. Siedzą potem przygnębieni w izbie i nagle Hanulka spontanicznie ujmuje rękę Jozy. Widzi to ksiądz, który tak niechętnie dawał im ślub, i uśmiecha się zdziwiony, ponieważ gest ten jawnie wyraża wzajemną miłość i zaufanie. Pojawiają się też sceny wyrażające satysfakcję erotyczną obojga małżonków, leżą razem w wielkim łóżku zaplątani w pierzynę, wyglądają na bardzo szczęśliwych i paplają jak dzieci. To wtedy zakochana Hanulka mówi do męża: Jozo, jesteś piękny²6.

Joza, w opowiadaniu i w filmie, jest wyraźnie idealizowany - staje się coraz bardziej sympatyczny i pociągający, pięknieje, objawia przyrodzoną dobroć, wrażliwość, czułość i opiekuńczość. Nie jest wykształcony, ale ma za to wiele innych zalet, które to znakomicie rekompensują. Podkreślanie wyjątkowości głównego bohatera, nasilającej się pod wpływem miłości, świetnie mieści się w formule klasycznego melodramatu. Ale historia Hanulki i Jozy przywołuje jeszcze inne skojarzenie - z baśnią, w której królewna poślubia głupiego Jasia. Po dokonaniu heroicznego czynu Jaś żeni się z królewną, której nikt nie pyta o zdanie na jego temat - ona i po-

26 Petra Knaiflová zinterpretowała miłość Hanulki i Jozy psychoanalityczną metodą Carla Gustava Junga jako idealny związek animy i animusa. Por. Jozova Hanule Kvĕty Legátové a její interpretace metodou analytické psychologie, http://is.muni.cz/th/53238/ff_m/DP-Jozova_Hanule_metodou_analyticke_ps.pdf (dostęp: sierpień 2012). 
łowa królestwa stanowią przecież nagrodę dla zwycięzcy. Baśń zwykle tu właśnie się kończy, nie wiadomo, jak ułożyło się to wysoce przypadkowe i niedobrane małżeństwo. Tradycyjnie zakłada się, że bardzo dobrze. Jaś udowodnił, że jest dzielniejszy, mądrzejszy i bardziej wartościowy niż rodowity książę, jakiego królewna spodziewała się poślubić, więc zakochuje się w nim, doceniając jego zalety. Opowiadanie Legátovej i film Trojana przekonują, że takie baśniowe historie jednak się zdarzają.

Hanulka nie tylko zakochuje się w Jozie, zaczyna także dostrzegać piękno miejsca (znaczna $\mathrm{w}$ tym zasługa wystudiowanych zdjęć Asena Śopova), gdzie rzucił ją Los - w melodramacie zawsze pisany z dużej litery, bo to on wyznacza kochankom czekające ich przeznaczenie. Łagodne stoki Beskidów, Żelary z malowniczymi chatami porozrzucanymi na wzgórzach, a także ludzie, którzy zdolni są zarówno do dobrego, jak i do złego. W opowiadaniu Legátovej Eliška przedstawia Żelary jako miejsce dzikie, egzotyczne i przerażające: miejsce mojego potępienia (s. 45), w Żelarach wszystkie domostwa sa samotne (s. 43), w Żelarach nie wiedza, co to płot (s. 44), dostałam się w tryby jakichś idiotycznych tradycji dzikiego plemienia (s. 50), tutaj od pierwszego dnia uświadomiono mi, że jestem kobieta (s. 56), kiedy w końcu tu zwariuje (s. 56). Na koniec: Spotykałam się z przerażajacym zacofaniem, zwyrodniałym egoizmem, bezmyślna chciwościa - ale też z anielska pokora, cierpliwościa, bohaterstwem i miłościa (s. 112).

Filmowe poznawanie Żelar przez Hanulkę dokonuje się stopniowo, jako miejsca na pewno wielce egzotycznego dla niej-i dla widzów - gdzie można jednak posmakować prawdziwego życia w całej jego żywiołowości i niejednoznaczności, odkryć autentyzm uczuć i doświadczyć złożonych stosunków międzyludzkich. W wejściu w zamknięty świat Żelar pomagają Hanulce kobiety: niezależna Žeňa Bojarová, która samodzielnie gospodarzy i wychowuje rezolutną córeczkę Helenkę, i stara Lucka Vojničová, wiejska znachorka - Joza mądrze znalazł do zamieszkania chałupę stającą blisko ich domów. Žeňa uczy Hanulkę gotowania i prowadzenia domu, a Lucka zabiera ją "do porodów” i zapoznaje z leczniczymi właściwościami ziół. Obie kobiety tak naprawdę uczą ją odkrywania w sobie „talentu do szczęścia”. Powoli Żelary z miejsca nienawistnego zesłania zamieniają się w prawdziwy dom Hanulki, wyznaczony jej przez Los do życia razem z Jozą.

Trwa jednak wojna i związane z nią dramaty dotykają nawet odległych Żelar. Gdy Hanulka zostaje żoną Jozy, do ich chaty przychodzą żandarmi prowadzeni przez sołtysa, by sprawdzić jej dokumenty. Joza przyjmuje żołnierzy wódką, co skutecznie usypia ich podejrzliwość. Pobity przez Jozę Michał woła w furii, że Hanulka ukrywa się w Żelarach 
i że jest zagrożeniem dla całej wsi, ale sąsiedzi nie dają się przestraszyć. Następne dwa wydarzenia są tragiczne. Gdy Hanulka gubi się w lesie, widzi - schowana w zaroślach - jak niemieccy żołnierze prowadzą płaczącą głośno kobietę, a potem natyka się na leśniczówkę, obok której wiszą trzej mężczyźni - to rodzina leśniczego ukarana za pomoc udzielaną partyzantom. W czasie pasterki Niemcy nakazują wiernym wyjście z kościoła i patrzenie, jak zabijają klęczącego mężczyznę, który ukrywał wroga Rzeszy.

Nastaje wiosna 1945 r. Do Żelar trafia oddział rosyjskich żołnierzy. Zostają radośnie przyjęci przez mieszkańców wsi, razem piją i śpiewają, świętując bliski koniec wojny. Młodziutki rudowłosy sołdat mówi do Hanulki: Przypominasz mi moja siostrę. Nad ranem, gdy wszyscy śpia, młody Gorčik, żądny zemsty na żonie, która związała się z jego ojcem, przyprowadza do ich chaty pijanego rosyjskiego żołnierza, by ją zgwałcił. Stary Gorčik zabija żołnierza i syna. Inny żołnierz strzela do Gorčika. Tak rozpętuje się piekło. Rozbudzeni, nie do końca trzeźwi i przerażeni żołnierze zaczynają strzelać dookoła, a uzbrojeni chłopi podejmują z nimi walkę. Ginie ksiądz, Žeňa zostaje zgwałcona, mały Vratislav Lipka przeprowadza uciekinierów ze wsi na wysepkę pośrodku bagien, Joza doprowadza tam rannych, Hanulka ich opatruje. Joza natyka się na rudowłosego żołnierza, który tonie w bagnie, w wyciągniętej ręce trzyma uniesiony do góry pistolet. Podsuwa mu gałąź, aby chłopiec mógł się jej uchwycić i wydostać $z$ topieli, ale żołnierz jej nie łapie, tylko strzela i tonie. Nauczyciel sprowadza inny oddział rosyjski, zapewniając jego dowódcę, że tu niet faszystow, walka wreszcie się kończy. Rosjanie udzielają pomocy rannym i znowu przyjaźnie odnoszą się do mieszkańców Żelar, traktując śmierć, gwałty i dokonane zniszczenia jak nic nieznaczący epizod wojenny. Postrzelony Joza umiera, Hanulka płacze nad jego ciałem.

Sekwencja wyzwolenia Żelar przez Armię Czerwoną radykalnie zrywa $\mathrm{z}$ upowszechnionym po wojnie heroicznym stereotypem szlachetnych żołnierzy radzieckich niosących wolność narodom ciemiężonym przez hitlerowców. Wiedza o zachowaniach sołdatów z pierwszych oddziałów szturmowych, zwykle zdziczałych i pijanych, przez ponad pół wieku utrzymywana była w tajemnicy w krajach zależnych od Rosji. Oficjalna propaganda wyrażała - jak czeska poezja z tamtych lat - „radość z wyzwolenia i ocalenia ludzkich wartości, wdzięczność dla Armii Radzieckiej, która wolność przyniosła" ${ }^{\prime 27}$. Relacja Legátovej i Trojana objawia nową prawdę o końcu wojny w Żelarach, jej podstawą nie jest czesko-ro-

27 Józef Magnuszewski, Historia literatury czeskiej. Zarys, Zakład Narodowy im. Ossolińskich - Wydawnictwo, Wrocław 1973, s. 330. 
syjska wrogość, ale słabość ludzkich charakterów, nadmiar wypitej wódki i łatwość w pociąganiu za spust karabinów.

Klasyczna formuła melodramatu dopuszcza tylko dwa rozwiązania finałowe: kochankowie żyli razem długo i szczęśliwie oraz rozstali się - z różnych powodów, najczęściej śmierci któregoś z nich lub nawet obojga. Nim w Żelarach rozpętała się walka, Hanulka i Joza, szczęśliwi i nieco podchmieleni, leżąc na łące, prowadzą niby zabawową, ale $\mathrm{w}$ istocie ważną rozmowę. Ona mówi: Może ci ucieknę..., on: Jesteś wolna. Możesz odejść [...]. Jutro, za tydzień. Może ktoś na ciebie czeka?, ona: Nikt na mnie nie czeka, nikt. Oboje mają więc świadomość, że koniec wojny przyniesie znaczącą zmianę $\mathrm{w}$ ich małżeństwie, która podkreśli istniejące między nimi różnice. Hanulka nie będzie już musiała ukrywać się w Beskidach, zacznie studiować medycynę i może nie zechce wrócić do Żelar. A Joza potrafi funkcjonować tylko na wsi, jego marzeniem jest kupno stada owiec i spokojne gospodarowanie. Los, który wcześniej zetknął ich ze sobą i dał im dwa lata nieoczekiwanego szczęścia, teraz sam rozwiązuje potencjalny konflikt między nimi. Joza umiera, Hanulka jest wolna - widzowie zalewają się łzami.

Rodowód nazwy Żelary da się wywieść od czeskich słów žel - „szkoda, niestety" oraz žal - „,żal, smutek" ${ }^{\prime 28}$. Przez dwa lata spędzone w beskidzkiej wsi Hanulka doświadczyła niezwykłych przeżyć związanych z odwzajemnioną miłością do Jozy i poznaniem radykalnie innego życia niż to, jakie dotąd prowadziła. Czas spędzony w Żelarach stał się kluczowy dla jej dalszej egzystencji. W opowiadaniu Legátovej po powrocie do Brna Hanulka zapadła na głęboką depresję, potem znowu zaczęła pracować w szpitalu, odrzuciła oświadczyny Richarda, który przyjechał z USA, bo wiedziała, że w jego objęciach [będzie] tęsknić do Jozy (s. 145). Może już nigdy nie uwolni się od pamięci o Jozie i Żelarach, ostatnie zdania opowiadania brzmią bowiem znamiennie: Poruszam się jak żotnierz, któremu rytm kroków wybija werbel. Moja dusza mnie opuściła. Bładzi po górskich zboczach i szuka niepotrzebnych grobów (s. 145). Film Trojana kończy się sceną równie symboliczną, ale w wymiarze kinowym, obrazowym. Po latach - nie wiadomo ilu, można sądzić, że około dwudziestu - do Żelar, gdzie stoją nowe murowane domy kryte dachówką, przyjeżdża samochodem Eliška, jest postarzała, nosi okulary. Towarzyszy jej posiwiały Richard. Podchodzą do ruin chaty, w której Hanulka mieszkała z Jozą. Nagle zza jej węgła wyłania się stareńka Lucka. Kobiety witają się serdecznie. Żyjesz? - pyta rozrzewniona Hanulka. Sama nie wiem. Wcale nie jestem tego pewna - odpowiada Lucka

28 Leszek Engelking, Opowiadania wyjęte z szuflady, s. 21. 
filuternie, dystansując się do własnego istnienia i minionego czasu. Kobiety śmieją się serdecznie i ten ich śmiech, z którego Richard jest wyłączony, wprowadza radosną, po czesku optymistyczną nutę w smutek zakończenia filmu.

Ondřej Trojan uczynił z Żelarów wierną adaptację opowiadania Květy Legátovej Hanulka Jozy, ale z oczywistych względów stworzył własną, wizualną wersję ekranową zapożyczonej historii. Wpisał ją w formułę melodramatu o przypadkiem skojarzonych małżonkach, którzy zaczynają kochać się po ślubie i uczynił z niej „dyspozycję wykonawczą” dla opowiadania Legátovej. Konsekwentnie respektował założenia klasycznego gatunku, snując opowieść o niezwykłej miłości Hanulki i Jozy. Rzadko zawodził oczekiwania widzów, bazował na fabularnych i narracyjnych schematach, ale chętnie wzbogacał swój film elementami humoru, którym kontrapunktował sceny brutalne i okrutne.

Wielka literatura opowiadająca o niedobranych związkach małżeńskich nigdy nie pociesza czytelników sugestią, że między małżonkami zrodzi się nagle wielka miłość, która zniweluje obojętność, uprzedzenia, wstręt i nienawiść - Dzieje Tristana i Izoldy Josepha Bédiera, Effi Briest Theodora Fontane, Pani Bovary Gustave'a Flauberta, Noce i dnie Marii Dąbrowskiej. Mniej wytrawna literatura lubi upiększać świat i dawać swym odbiorcom życzliwe pocieszenie. Podobnie jak filmy, które powstają na jej podstawie. Czy to komuś szkodzi? Oczywiście że nie, udowadnia tylko starą prawdę, że romantyczna wersja małżeństwa jest bardziej pociągająca - w sztuce i w życiu. 